КОМУНІКАТИВНА ПІДГОТОВКА МАЙБУТНІХ ПОЛІЦЕЙСЬКИХ НА ЗАНЯТТЯХ З УКРАЇНСЬКОЇ МОВИ ПРОФЕСІЙНОГО СПРЯМУВАННЯ

\title{
COMMUNICATIVE TRAINING OF FUTURE POLICE OFFICERS IN UKRAINIAN PROFESSIONAL LANGUAGE CLASSES
}

DOI https://doi.org/10.32843/2663-

$6085 / 2021 / 40.36$

\section{Мариківська Г.А.,}

канд. пед. наук,

доцент кафедри соціально-

гуманітарних дисциплін

Харківського національного

університету внутрішніх справ у статті доводиться актуальність проблеми комунікативної підготовки майбутніх поліцейських саме на заняттях з української мови професійного спрямування, оскільки вільне володіння рідною мовою сприятиме не тільки профресійному розвитку майбутніх поліцейських, а й формуванню їхньої національної свідомості, моральних переконань, української ментальності, що необхідно для виховання нового покоління правоохоронців.

Успішне спілкування дозволить кожному поліцейському виконувати свої профресійні обов'язки, досягати міжособистісного взаєморозуміння, збагачувати духовне світосприйняття.

Метою нашої статmі $\epsilon$ розгляд деяких напрямів комунікативної підготовки майбутніх поліцейських на заняттяя з української мови професійного спрямування. Комунікативна підготовка майбутніх поліцейських - це спеціально організований, цілеспрямований процес формування та розвитку комунікативного потенціалу полічейських із метою якісної реалізації професійних завдань, які вимагають здійснення комунікативної діяльності.

У статті розглянуті фрактори успішного проведення бесіди й опитування у професійному спілкуванні, подані рекомендаціі щодо їх успішного проведення.

Ми вважаємо, що на заняттях у ЗВО, у m. ч. на заняттях з української мови профресійного спрямування, для досягнення основної мети навчання слід використовувати дидактичні ігри, зокрема ділові та рольові. Використання дидактичних ігор у процесі підготовки фрахівців різних спеціальностей сприяє фрормуванню інтересу до навчання, підвищенню есрективності цього процесу, впливає не тільки на навчально-пізнавальну діяльність, а й на особистість студентів. Ці ігри є ефрективним інструментом розвитку інтелекту спеціалістів, котрі беруть у них участь, розвитку їхніх творчих можливостей під час пошуку рішень завдань, а також репетицією та перевіркою того, як студенти вміють користуватися словом у певній психологопедагогічній ситуації.

3 метою вдосконалення процесу комунікативної підготовки поліцейських доцільно розробити систему рольових і ділових ігор, під час яких студенти будуть оволодівати різноманітними комунікативними вміннями.

Ключові слова: комунікативна підготовка, спілкування, рольова гра, ділова гра, бесіда, інтерв'ю, опитування.

training of new generation of police officers. Successful communication will allow each police officer to perform their professional duties, achieve interpersonal understanding, and enrich the spiritual worldview.

The ability to communicate, to achieve mutual understanding in the process of performing professional functions is the most impor tant basis for high efficiency of a police officer, which involves the ability to navigate in various professional communication situations, find the necessary means, methods and techniques of communication depending on the purpose of communication, the ability to persuade an interlocutor, to build a monologue and dialogue correctly, to behave correctly in conflict situations, etc.

The purpose of our article is to consider some areas of communicative training of future police officers in professional Ukrainian language classes.

Communicative training of future police officers is a specially organized, purposeful process of formation and development of communicative potential of police officers for the purpose of qualitative realization of the professional tasks, which are demanding the realization of communicative activity.

The article considers the factors of successful interviewing and interviewing in professional communication: preliminary preparation, establishing contact, choosing a distance for communication, overcoming barriers to communication, the emergence of cognitive and emotional interest in law enforcements. Recommendations for suc cessful interviews and interviews in professional communication are given.

We believe that didactic games, in particular business and role-playing games, should be used to achieve the main goal of education in higher education classes, in particular in professional Ukrainian language classes.

The use of didactic games in the process of training specialists in various specialties contributes to the formation of interest in learning, increasing the effectiveness of this process, affects not only the educational and cognitive activities, but also the personality of students. These games are an effective tool for developing the intelligence of specialists involved in them, the development of their creative abilities in finding solutions to problems, as well as rehearsals and testing of how students can use the word in a particular psychological and pedagogical situation.

In order to improve the process of communicative training of police officers, it is advisable to develop a system of role-playing and business games, during which students will master a variety of communication skills.

The article proves the relevancy of the problem of communicative training of future police officers in Ukrainian language classes, as fluency in the native language will contribute not only to the professional development of future police officers, but also to the formation of their national consciousness, moral beliefs, Ukrainian mentality, which is necessary for
An example of the business game "Interview" is given, which we used during the teaching of the Ukrainian language for professional purposes in a higher education institution. Key words: communicative training, communication, role play, business game, conversation, interview, survey. 
Постановка проблеми у загальному вигляді. Зміни, що відбуваються у різних галузях суспільства, потребують удосконалених підходів до профресійної підготовки фрахівців у ЗВО. Не $є$ винятком і профресійна підготовка майбутніх поліцейських, яка передбачає виховання нового покоління правоохоронців, котрі мають здійснювати дієву, ефективну, прозору діяльність із метою забезпечення конституційного ладу України. Діяльність повинна бути побудована на загальнолюдських цінностях, принципах відкритості та прозорості, гуманізму та демократії, усвідомлення прав і свобод людини як найбільших здобутків суспільства. Виховання нового покоління правоохоронців $€$ складовою частиною побудови якісно нової європейської держави із превалюванням людських цінностей, прав і свобод.

У зв'язку із цим актуалізується необхідність якісної підготовки поліцейських до профресійної діяльності, яка за своєю природою є комунікативною. Ядром контакту з іншими людьми є спілкування, що дозволяє кожному поліцейському виконувати свої профресійні обов'язки, досягати міжособистісного взаєморозуміння, збагачувати духовне світосприйняття. Уміння спілкуватися, досягати взаєморозуміння у процесі виконання професійних фрункцій є основою високої ефрективності праці поліцейських, а це передбачає вміння орієнтуватися у різноманітних професійних комунікативних ситуаціях, знаходити потрібні засоби, способи та прийоми спілкування залежно від мети спілкування, чітко висловлювати власну думку, аргументовано дискутувати, переконувати співрозмовника, правильно будувати монолог і діалог, правильно поводитися у конорліктних ситуаціях тощо. Отже, якісна підготовка майбутніх поліцейських неможлива без якісної комунікативної підготовки.

Можливість якісної комунікативної підготовки може бути реалізована на заняттях з української мови професійного спрямування, оскільки вільне володіння рідною мовою сприятиме не тільки професійному розвитку майбутніх поліцейських, а й фрормуванню їхньої національної свідомості, моральних переконань, української ментальності, необхідних для виховання нового покоління правоохоронців.

Аналіз останніх досліджень і публікацій. Аналіз наукової літератури свідчить про те, що вчені розглядали різні аспекти досліджуваної проблеми. Зокрема, роботи О. Бодальова, Ю. Ємельянова, Г. Ковальова, О. Леонтьєва та ін. присвячені розвитку комунікативного потенціалу особистості; М. Корнєва, О. Коропецької та ін. - дослідженню місця й ролі спілкування у розвитку та становленні особистості; О. Боброва, С. Богдан, М. Васильєвої, Н. Вітюк, Р. Дружененко, С. Єлканова, М. Казнаджиєвої, А. Мудрика, А. Нікітіної, С. Омельчук, О. Усової та ін. - розвитку комунікативних і мовленнєвих умінь; І. Варнавської, Ю. Жукова, Н. Завіниченко, В. Зливкова, О. Колодич, С. Макаренко,
О. Павленко, А. Панфрілової, Л. Петровської, П. Растянникова, В. Романової, Є. Руденського, В. Черевко та ін. - фрормуванню комунікативної компетентності особистості; В. Барковського, Т. Гончар, Н. Дикої, О. Крсек, Г. М'ясоїд, О. Рембач, О. Уваркіної, В. Будянської - фрормуванню комунікативної та мовленнєвої культури, а також культури ділового спілкування; В. Розова - основам базової комунікації професійно-психологічної підготовки правоохоронців.

Виділення не вирішених раніше частин загальної проблеми. Незважаючи на велику кількість робіт, у яких так чи інакше розглядаються питання комунікативної підготовки фрахівців, існує потреба визначення шляхів фрормування та розвитку комунікативного потенціалу майбутніх поліцейських.

Метою статті $€$ розгляд деяких напрямів комунікативної підготовки майбутніх поліцейських на заняттях з української мови професійного спрямування. Завдання статті: 1) розгляд опитування (інтерв'ю, бесіди) як методу отримання інорормації; 2) виокремлення фракторів успішного проведення інтерв'ю, бесіди; 3) показ формування вмінь застосовувати методи бесіди й інтерв'ю під час рольових і ділових ігор.

Виклад основного матеріалу. На нашу думку, комунікативна підготовка майбутніх поліцейських - це спеціально організований, цілеспрямований процес фрормування та розвитку комунікативного потенціалу поліцейських із метою якісної реалізації професійних завдань, що вимагають здійснення комунікативної діяльності.

У статті ми розглянемо фрормування вмінь і навичок здійснення опитування у професійному спілкуванні.

Опитування як метод дає змогу за короткий проміжок часу одержати велику кількість інформації. Розрізняють опитування групове (опитування групи) й індивідуальне (опитування кожної людини окремо). Серед усних методів опитування найчастіше вживаними $є$ інтерв'ю та бесіда.

Як зазначає Р. Павелків, інтерв'ю є методом отримання необхідної інфрормації шляхом безпосередньої цілеспрямованої бесіди інтерв'юера з респондентом, а бесіда - це метод одержання інфрормації за допомогою вербальної комунікації під час вільного діалогу між дослідником і досліджуваним на певну тему. У разі проведення інтерв'ю двосторонній зв'язок обмежений, інтерв'юер лише фріксує відповіді респондента, зберігаючи нейтральну позицію, а бесіда не обмежена у часі, наявний двосторонній зв'язок між дослідником і респондентом [5].

За кількістю опитуваних і метою дослідження розрізняють індивідуальні, групові та масові інтерв'ю.

Індивідуальні інтерв'ю зазвичай $€$ вільними, нестандартизованими. Їхньою головною метою $€$ вивчення особистісних характеристик людини. Групові інтерв'ю проводяться одночасно з усією 
групою та передбачають проведення групової дискусії з певного кола питань. Масові інтерв'ю призначені для дослідження масових явищ, громадської думки, настроїв, соціальної напруженості тощо [5].

О. Цільмак, С. Яковенко визначають фрактори успішного проведення бесіди й опитування: попередню підготовку, установлення контакту та довірливих стосунків з об'єктами правоохоронної діяльності, обрання дистанції, подолання бар'єрів спілкування, виникнення в об'єкта правоохоронної діяльності когнітивної й емоційної зацікавленості до себе, установлення довірливих стосунків, що можливе в умовах почуття безпеки й упевненості одне в одному [6].

О. Цільмак, С. Яковенко вказують, що основною частиною опитування або бесіди $є$ процес отримання необхідної інорормації. Тут важливими $€$ уміння слухати, чути й почути; бути спостережливим; використовувати прийоми проведення опитування або бесіди [6].

На нашу думку, навчати ефективно застосовувати бесіду й опитування доцільно під час рольових і ділових ігор.

За С. Рубінштейном, основною метою навчання $€$ підготовка до майбутньої самостійної трудової діяльності, основним способом - засвоєння узагальнених результатів того, що створено попередньою працею людства; засвоюючи результати минулої суспільної праці, людина готується до власної трудової діяльності.

«Діяльність учнів в умовах ігрових методів навчання подібна до структури їхньої майбутньої профресійної діяльності, де також має місце робота на кінцевий результат, розподіл і кооперація праці. Це, у свою чергу, створює обстановку умовної практики, зближує навчальну та майбутню професійну діяльність» [4, с. 74]. Ми вважаємо, що на заняттях у ЗВО, зокрема на заняттях з української мови професійного спрямування, для досягнення основної мети навчання слід використовувати дидактичні ігри, зокрема ділові та рольові.

На ефрективність використання дидактичних ігор у ЗВО вказували різні дослідники. Так, І. Куліш зазначала, що «використання дидактичних ігор у підготовці фрахівців різних спеціальностей сприяє формуванню інтересу до навчання, підвищенню ефективності цього процесу, підготовці студентів до використання теоретичних знань у практичних ситуаціях (особливо ділові ігри), зміні негативних стереотипів щодо навчання, впливає не тільки на навчально-пізнавальну діяльність, а й на особистість студентів» [4, с. 71]. М. Крюков вважає: «Поява ділових ігор створила новий вид діяльності представників найрізноманітніших спеціальностей. Якими би не були уявлення про ділові ігри, прихильники цих уявлень одноголосні у тому, що ділова гра $\epsilon$ ефективним інструментом розвитку інтелекту спеціалістів, які беруть у ній участь, розвитку їх творчих можливостей у пошуку рішень завдань» [3, с. 177].
А. Капська, підкреслюючи значення застосування дидактичних ігор у 3ВО, відзначала: «Використання у професійній підготовці ділових і рольових ігор - це по суті своєрідна репетиція та перевірка того, як студенти вміють користуватися словом у заданій психолого-педагогічній ситуації. Обидва види ігор дозволяють програвати найрізноманітніші ситуації, у яких кожен студент, виступаючи то в одній, то в іншій ролі та володіючи виконавсько-мовленнєвими вміннями, має змогу довести доцільність своїх підходів до розв'язання тих чи інших педагогічних проблем» [1, с 71].

І. Куліш виокремлює такі поняття, як «рольова гра», «ділова гра». Ці поняття мають спільні та відмінні риси. Дидактичні ігри за способом організації можуть бути ситуативні, рольові та ділові. Рольові та ділові ігри є дидактичними, цими іграми досягається певна навчальна мета, важливим моментом у них $є$ сам процес проведення гри. Рольова гра відрізняється від ділової тим, що у першій присутній будь-який сюжет із життя навколо нас або уявний, у діловій грі ситуація стосується майбутньої професії студентів чи безпосередньо професійного роду заняття учасників [4].

Приклад ділової гри, яку ми застосовували під час навчання української мови професійного спрямування у ЗВО.

\section{Гра «Інтерв'ю»}

Необхідний час: 30 хвилин.

Мета гри: потренуватися в умінні відповідати на питання журналістів, а також обходити небажані питання, в умінні використовувати вербальні та невербальні засоби спілкування.

Розмір групи: не менше 4-х осіб.

Порядок дій: залежно від задуму гри один учасник виконує роль журналіста, котрий бере інтерв'ю в поліцейського, а інший учасник - поліцейський, який повинен відповідати на питання журналіста.

1. Виберіть двох студентів.

2. Поясніть, що один із них повинен зіграти роль поліцейського, а інший - роль журналіста. На інтерв'ю відводиться 5 хвилин.

3. Решта студентів, сидячи на своїх місцях, повинна фріксувати всі помилки, яких припустилися поліцейський і журналіст.

4. Після гри обговоріть результати (досягли учасники гри наміченої мети чи ні).

5. Виберіть ще двох осіб і запропонуйте їм також зіграти у цю гру (можна придумати іншу ситуацію).

Роль А.

Ви поліцейський. Минулого тижня Ви зіштовхнулися із ситуацією. На вулиці сварилося подружжя. Чоловік використовував нецензурну лексику, погрожував жінці через те, що вона залицялася до спільного знайомого. Поведінка чоловіка була неконтрольованою 3 перепадами настрою від пригнічення до агресії. Поліцейський усе зробив 
за алгоритмом: доповів оперативному черговому, представився, припинив правопорушення (розвів сторони конорлікту), забезпечив безпеку жінки, однак наступного дня чоловік із жінкою подали скаргу на поліцейського, що той діяв не за правилами, порушував закон, що ніхто не сварився, що поліцейський усе вигадав.

Сьогодні ви виступаєте на телебаченні у популярній передачі та хотіли би розповісти про досягнення у роботі свого відділу. Про той інцидент вам би не хотілося сьогодні згадувати, тим паче, що звинувачення на адресу вашого відділу були незаслуженими, однак ви не впевнені у тому, що ведучий вас сьогодні не спитає про цей випадок, оскільки знаєте, що чоловік і жінка об'єдналися проти Вас і пишуть скарги в усі відомства.

Роль В.

Сьогодні Ви берете інтерв'ю в поліцейського. Ви неодмінно хотіли би спитати його щодо цього інциденту.

Готові питання журналіста:

- Розкажіть, як працює Ваш відділ.

- Відомо, що минулого тижня стався такий випадок...

- Як особисто ви ставитися до питань порушення закону?

Журналіст може ставити й інші питання залежно від ситуації.

Завершення: для цієї гри можна підібрати різні ситуації.

Висновки. Отже, у процесі професійної підготовки поліцейських доцільно фрормувати у них уміння спілкуватися, досягати взаєморозуміння у процесі виконання професійних функцій, орієн- туватися у різноманітних професійних ситуаціях, знаходити потрібні засоби, способи, прийоми спілкування залежно від мети спілкування, чітко висловлювати власну думку, аргументовано дискутувати, переконувати співрозмовника, правильно будувати монолог і діалог, правильно поводитися у консрліктних ситуаціях. У процесі комунікативної підготовки поліцейських важливим є вміння здійснювати опитування у профресійному спілкуванні. Цього можна навчатися у процесі рольових і ділових ігор.

3 метою вдосконалення процесу комунікативної підготовки поліцейських доцільно розробити систему рольових і ділових ігор, під час яких студенти будуть оволодівати різноманітними комунікативними вміннями.

\section{БІБЛІОГРАФІЧНИЙ СПИСОК:}

1. Капська А.Й. Гра як активний метод навчання студентів майстерності слова. Рідна школа. 1991. № 10. С. 71-73.

2. Кочерган М.П. Загальне мовознавство : підручник. Київ : Академія, 2006. 463 с.

3. Крюков М.М. Деловая игра как способ развития интеллекта на основе преодоления образа. Новосибирск, 1988. С. 177-194.

4. Куліш І.М. Дидактична гра як засіб активізації навчальної діяльності студентів університету : автореф. дис. ... канд. пед. наук: 13.00.09, Черкаси, 2001. $191 \mathrm{c}$.

5. Павелків Р.В. Загальна психологія : підручник. Київ : Кондор, 2009. 567 с.

6. Цільмак О.М., Яковенко С.І. Професійно-психологічна підготовка працівників : підручник. Одеса : ОДУВС, 2012. 140 c. 